Original Article

\title{
HEPATOPROTECTIVE ACTIVITY OF THE WHOLE PLANT OF NEPTUNIA PROSTRATA L. IN CARBON TETRACHLORIDE INDUCED RATS
}

\author{
HONEY JAJO ${ }^{*}$, RAJAT GHOSH ${ }^{2}$ \\ ${ }^{1}$ Himalayan Pharmacy Institute Majhitar, East Sikkim 737136, '2Department of Pharmacy Tripura University Suryamaninagar 799022 \\ "Email: jajohoney@gmail.com
}

Received: 04 Aug 2021, Revised and Accepted: 10 Oct 2021

\begin{abstract}
Objective: The aim of this study is to investigate the hepatoprotective activity of the whole plant of Neptunia Prostrata L.

Methods: The whole plant was collected and identified as Neptunia Prostrata L. The collected plants were shade dried and pulverized to fine powdered of particle size (\#) 40. It was then defatted with petroleum ether for 24 hour and soaked with methanol and ethanol, respectively. The extracts was filtered and distilled off using a rotary evaporator. The phytochemical screening of the extracts was carried out and thin layer

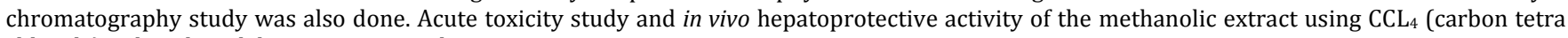
chloride) induced model was investigated.
\end{abstract}

Results: The phytochemical screening revealed the presence of alkaloids, glycosides (saponins), flavonoids, tannins, carbohydrates, proteins, phenolic, steroids and terpenoids. Thin-layer chromatography of the methanolic and ethanolic extracts with their fractions using different solvents were performed by taking petroleum ether and ethyl acetate (2:8) as mobile phase system and were able to observe the presence of many spots. Oral administration of methanolic extract of Neptunia prostrata at doses till $2000 \mathrm{mg} / \mathrm{kg}$ was found safe and shows good hepatoprotective activity by showing decreased levels of serum SGOT (serum glutamate oxaloacetate transaminase), SGPT (serum glutamate pyruvate transaminase) and ALP (alkaline phosphatase) when compared with the standard drug silymarin.

Conclusion: The preliminary phytochemical screening of the methanol and ethanolic extract shows phytoconstituents such as flavonoids, triterpenoids, tannins, saponins, alkaloids and chromatographic studies indicates the presence of several components in varying abundance. The decrease of serum bilirubin level by the methanolic extract of the plant shows hepatoprotective activity. It has confirmed the traditional claim for its use in the treatment of jaundice.

Keywords: Phytochemical, Methanol, Neptunia prostrata L, Ethanol and hepatoprotective

(C) 2021 The Authors. Published by Innovare Academic Sciences Pvt Ltd. This is an open-access article under the CC BY license (https://creativecommons.org/licenses/by/4.0/) DOI: https://dx.doi.org/10.22159/ijcpr.2021v13i6.1913 Journal homepage: https://innovareacademics.in/journals/index.php/ijcpr

\section{INTRODUCTION}

Liver disorder is the main challenged faced by the world today. Herbal plants of liver protection contain a variety of chemical constituents like phenols, coumarins, monoterpenes, glycosides, alkaloids and xanthenes. Medicinal plants have fewer side effects and can be used irrespective of the age group [1]. Manifold number of plants and formulations have proved to have hepatoprotective activity; 160 phytoconstituents obtained from 101 plants have claimed liver protecting activity [2]. Neptunia prostrata is an annual floating aquatic herb distributed in lakes and marshy places all over India [3]. It is available in 25 different states of India including the north-eastern state such as Manipur, Tripura [4, 5]. It is grown wild and being cultivated as vegetable throughout Southeast Asia, particularly Thailand and Indo-China [6]. The tribals of North east India cultivate this plant as vegetable and medicinal plant purposes and also prepare various tasty delicacy dishes [7]. The whole plant has been used for different kinds of remedies like gastritis, acidity, constipation, dysentery [8] and also reported to possess antioxidant [9]anti-cancer [10] antimicrobial [11] anti-inflammatory, analgesic activities [12] refrigerant and astringent properties [13] laxative [14] and also for treatment of jaundice [15]. The roots of the plant are used in late stages of syphilis [16]. The preliminary phytochemical study revealed the presence of flavonoids, carbohydrates, anthroquinones, tannins and triterpenes in alcoholic extract [17]. Since there are no particular reports on hepatoprotective activity of leaves of the plant, it was considered worthwhile to evaluate hepatoprotective activity.

Carbon tetrachloride $\left(\mathrm{CCl}_{4}\right)$ is one of the most commonly used hepatotoxins in the experimental study of liver diseases. The hepatotoxic effect of $\mathrm{CCl}_{4}$ is largely due to its active metabolite, trichloromethyl radical [18]. The administration of $\mathrm{CCl}_{4}$ in rats enhances hepatic protein oxidation and results in the accumulation of $\mathrm{CCl}_{4}$ oxidized proteins in the liver [19]. The present study was conducted to evaluate the hepatoprotective effect of the extracts of whole plant of Neptunia prostrata on carbon tetrachloride induced liver damage in experimental rats.

\section{MATERIALS AND METHODS}

\section{Plant sample collection and identification}

The whole plant of Neptunia prostrata which was collected from Abhoynagar vegetable market. It was identified by a taxonomist at the Dept. of Botany, Tripura University, India.

\section{Processing of plant materials and extraction}

Fresh whole plant of Neptunia prostrata was washed thoroughly 2-3 times with running water and once with sterile distilled water. The collected whole plants were shade dried and pulverized to fine powdered of particle size (\#) 40 . The collected $400 \mathrm{gm}$ of powdered plant material was defatted with petroleum ether for $24 \mathrm{~h}$. and soaked with methanol and ethanol, respectively. The extracts was filtered and distilled off by using rotary evaporator. $18 \mathrm{gm}$ of crude ethanol extract was suspended into $100 \mathrm{ml}$ of distilled water to make $95 \%$ aqueous solution and fractioned sequentially with dichloromethane, ethyl acetate and isobutanol, respectively (each solvent $100 \mathrm{ml}$ ). The extracts were filtered through Whatman filter paper no. 1 and concentrated at $50{ }^{\circ} \mathrm{C}$ using rotary evaporator (Ika, Japan). The concentrated extracts were stored in airtight container at $4{ }^{\circ} \mathrm{C}$ refrigerator for further experiments $[20,21]$.

\section{Thin layer chromatographic (TLC) analysis}

Thin layer chromatography of the Neptunia prostrata methanolic extract NPME and Neptunia prostrata ethanolic extract NPEE was carried out. The NPEE and its fractions were also carried out for TLC 
study such as (NPIF Neptunia prostrata isobutanol fraction, NPEF Neptunia prostrata ethylacetate fraction, NPDF Neptunia prostrata dichloromethane fraction). It was performed in a prepared silica gel G coated alumina plate cutted suitably into $6 \mathrm{~cm}$ in length and $2 \mathrm{~cm}$ in width. The extracted material was dissolved in a minimum amount of their respective solvent used and spotted on the preactivated plates using capillary tube, TLC was run in petroleum ether: ethyl acetate (2:8) mobile phase system. Chromatogram was developed and dried in air. The extracts were chromatographed on silica-coated TLC plates (Sigma-Aldrich) [22].

\section{Phytochemical screening}

The methanolic extract and ethanolic extract were performed for phytochemical screening, which includes test for alkaloids [23], test for carbohydrates, tannins, phenols [24], test for glycosides, saponins [25], test for flavonoids, proteins, steroids, and terpenoids [26] were performed.

\section{In vivo hepatoprotective study}

Experimental animals: animal experimentation was carried out with minimum invasive procedures as per the guidelines of CPCSEA. The ethical clearance obtained was (IAEC/BCPSR/003/2016).

Acute toxicity study [27]: The acute toxicity study for methanolic extracts of Neptunia Prostrata whole plant was performed using albino rats. The animals were fasted overnight prior to the experiment and maintained under standard conditions. All the extracts were administrated orally in the increasing dose and found safe up to the dose of $2000 \mathrm{mg} / \mathrm{kg}$.

Evaluation of hepatoprotective activity [28]: Rats were divided into four groups of six animals each. All groups received $\mathrm{CCL}_{4}$ (2 $\mathrm{ml} / \mathrm{kg} / \mathrm{BW} / \mathrm{s}$. c) except group A. Group A (Normal control) animals were administered with normal saline $(10 \mathrm{ml} / \mathrm{kg}$, i. p). Group B experimental control received $\mathrm{CCL}_{4}$ : liquid paraffin $(1: 1,2 \mathrm{ml} / \mathrm{kg}$ body weight, i. p). Group C received standard drug silymarin (100 $\mathrm{mg} / \mathrm{kg}$, i. p). Test groups animals Group D were administered 200 $\mathrm{mg} / \mathrm{kg}$ of methanolic extracts in the form of aqueous suspension once daily after $\mathrm{CCL}_{4}$ administration for $15 \mathrm{~d}$. Animals were sacrificed $24 \mathrm{~h}$ after the last treatment. Blood was collected, allowed to clot and serum was separated at $2500 \mathrm{rpm}$ (revolution per minute) for $15 \mathrm{~min}$ and biochemical investigations were carried out. Liver was dissected out and used for histopathological studies.

Estimation of serum biochemical parameters: Serum biochemical parameters were estimated according to standard methods. The activity of the enzymes ALT, AST, and ALP was measured using commercial enzymatic biochemical diagnostic kits.

\section{RESULTS}

\section{Phytochemical screening}

The methanolic and ethanolic extract of the plant shows many phytochemicals such as alkaloids, glycosides (saponins), flavonoids, tannins, carbohydrates, proteins, phenolic, steroids and terpenoids etc. (table 1).

\section{TLC}

Thin-layer chromatography of the methanolic extracts and ethanolic extracts with their fractions was performed by taking petroleum ether and ethyl acetate $(2: 8)$ as mobile phase system and was able to observe the presence of many spots.

\section{Acute toxicity studies}

Oral administration of methanolic extract of Neptunia prostrata at doses till $2000 \mathrm{mg} / \mathrm{kg}$ body weight did not produce any significant behavioral change and during the experimental period, no death occurs. So, it was determined that the drug was safe up to 2000 $\mathrm{mg} / \mathrm{kg}$ body weight.

Table 1: Phytochemical test for methanolic and ethanolic extract of Neptunia Prostrata

\begin{tabular}{llll}
\hline S. No. & Phytochemical test & Methanol extract & Ethanol extract \\
\hline 1. & Alkaloid & + & + \\
2. & Glycosides & + & + \\
3. & Saponin & - & + \\
4. & Anthraquinone & + & + \\
5. & Flavonoids & + & + \\
6. & Tannins & + & + \\
7. & Carbohydrates & + & + \\
8. & Protein & + & + \\
9. & Phenolic & + & + \\
10. & Steroids & + & + \\
11. & Terpenoids & +
\end{tabular}

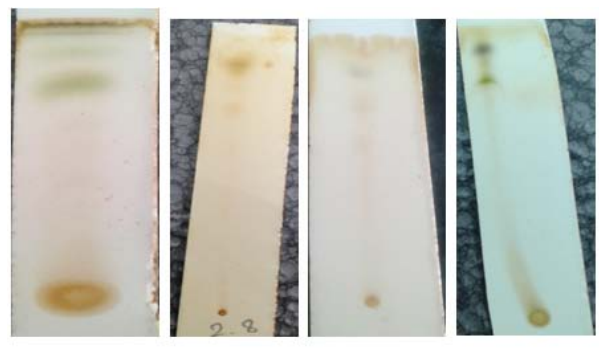

a) NPEE b) NPDF c) NPEF d) NPIF

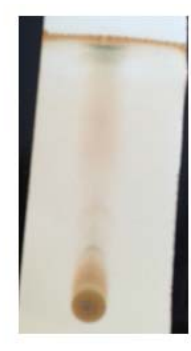

e) NPME

Fig. 1: Ethanolic extract and its fractions TLC of the extracts methanolic extract

\section{Hepatoprotective effect of NPME in $\mathrm{CCl}_{4}$-induced liver damage}

Effect of NPME on liver function parameters: $\mathrm{The}^{\mathrm{CCl}_{4}}$ induced hepatic injury was confirmed by measuring the activity of hepatic marker enzymes ALT, AST, ALP and total bilirubin of rats. A significant increase in the levels of ALT, AST, and ALP was observed in $\mathrm{CCl}_{4}$ treated rats from those of the control group. Administration of NPME (200 mg kg-1) significantly attenuated the elevation of these parameters. The hepatoprotective effect shown by NPME was almost comparable to that of silymarin (fig. 2). 


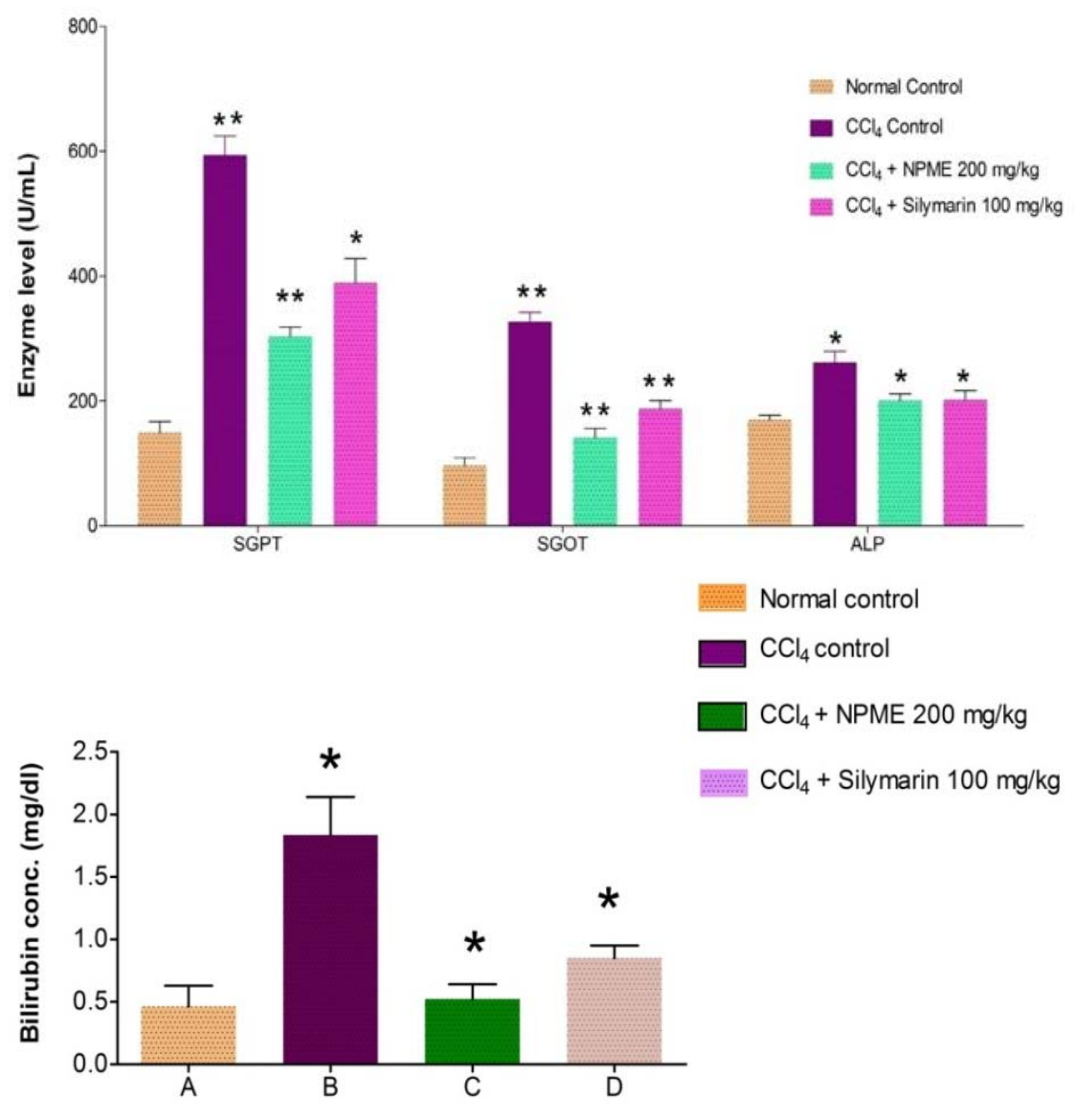

Fig. 2: Effect of NPME on liver function parameters

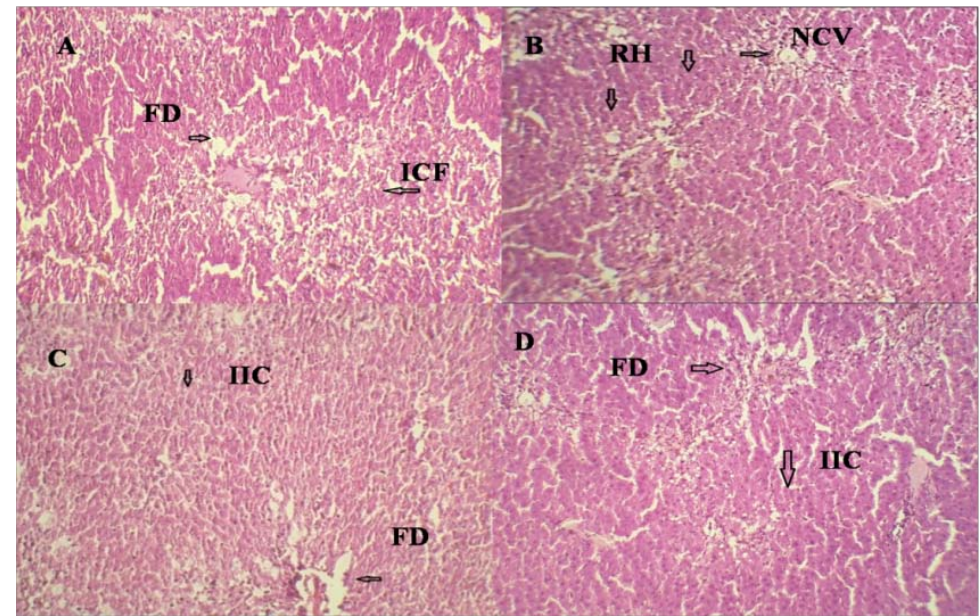

Fig. 3: Histopathological observations, a) Liver sections of $\mathrm{CCl}_{4}$ induced liver toxicity, b) Left arrow indicates fatty degeneration and right arrow indicates inflammatory cell infiltration, c) Liver section of normal control: left arrow shows normal central vein and down arrow indicates radiating hepatocytes, d) Liver section treated with NPME+CCL 4 : down arrow indicates infiltration of inflammatory cells and right arrow shows fatty degeneration, e) Liver section treated with Standard silymarin+CCL 4 : left arrow indicates fatty degeneration and down arrow shows infiltration of inflammatory cell

\section{DISCUSSION}

The preliminary phytochemical investigations of methanol and ethanol extracts has been performed and found the presence of phytoconstituents such as alkaloids, glycosides (saponins), flavonoids, tannins, carbohydrates, proteins, phenolic, steroids and terpenoids etc. (table 1) Thin-layer chromatography of the extracts by taking petroleum ether and ethyl acetate $(2: 8)$ as mobile phase system has observed the presence of many spots. (fig. 1). Phytochemical screening and thin-layer chromatography studies indicate the presence of several components in varying abundance.
Administration of $\mathrm{CCl}_{4}$ causes severe liver damage because it is metabolized by cytochrome $\mathrm{P}_{450}$ in hepatocytes, producing a highly reactive carbon centered trichloromethy radical, thereby initiating a chain of lipid peroxidation causing liver fibrosis. Increased levels of serum SGOT, SGPT and ALP of the $\mathrm{CCl}_{4}$ treated animals shows liver damage as the enzymes leak out from the liver into the blood at the instance of tissue damage which is always associated with hepatonecrosis [29]. The strength of a hepatoprotective drug to reduce the injurious effects or to preserve the normal hepatic physiological mechanisms that have been disturbed by a hepatotoxin is the index of its protective effects [30]. The oral 
administration of NPME at doses till $2000 \mathrm{mg} / \mathrm{kg}$ body weight did not produce any significant behavioural change and during the experimental period, no death occurs. So, it was determined that the plant extract was safe up to $2000 \mathrm{mg} / \mathrm{kg}$ body weight.

Biochemicals analysis: Serum levels of SGOT, SGPT, ALP and total bilirubin serve as hepatotoxicity indexes. $\mathrm{CCL}_{4}$ administration produces significant elevations of serum as compared to the normal control group indicating liver damage. Treatment of rats with NPME $\left(200 \mathrm{mg}+\mathrm{CCL}_{4}\right)$ caused a significant reduction in the values of SGOT, SGPT, ALPand total bilirubin (fig. 2).

Histological studies: The hepatoprotective effect of NPME was confirmed by histopathological examination of the liver tissue of control and treated animals. The histological architecture of $\mathrm{CCL}_{4}$ liver sections showed severe fatty degeneration of hepatocytes. However, administration of NPME $(200 \mathrm{mg} / \mathrm{kg})$ almost normalized these defects in the histological architecture to the level of normal control groups. It also shows more activity than the standard silymarin-treated groups, showing its potent hepatoprotective effects (fig. 3). The presence of phytoconstituents like flavonoids, triterpenoids, tannins, saponins, alkaloids are known to possess hepatoprotective activity [31].

\section{CONCLUSION}

The preliminary phytochemical screening and chromatographic studies indicates the presence of several phytoconstituents in varying abundance. The decrease of serum bilirubin level by the methanolic extract of the plant shows hepatoprotective activity. Hence, from the experimental evidence, it has confirmed the traditional claim of it's used as hepatoprotective.

\section{ACKNOWLEDGMENT}

The authors are thankful to PK Deb and R Chakraborty for their contributions in animal handling and recording of physiological parameters.

\section{FUNDING}

Nil

\section{AUTHORS CONTRIBUTIONS}

All authors have contributed equally.

\section{CONFLICT OF INTERESTS}

Declared none

\section{REFERENCES}

1. Zachariah SM, Aleykutty $\mathrm{Nb}$, Viswanad V, Halima OA. An overview on hepatoprotective activity of natural products. RJPT. 2012;5:317-21.

2. Fasalu Rahiman OM, Rupesh Kumar M, Tamizh Mani T, Mohamed Niyas K. A review of hepatoprotective natural products. IJPSRR. 2011;8(1):80-4.

3. Turner BL, Fearing OS. The basic chromosome number of the genus Neptunia (Leguminosae-Mimosoideae). Published by California Botanical Society. 1960;15:184-7.

4. Chopra RN, Nair SL, Chopra IC. Supplement to glossary of Indian medicinal plants. New Delhi: Council of Scientific and Industrial Research; 1986. p. 73.

5. Choudhury SN, Paul SB, De B. Preliminary phytochemical evaluation and antibacterial screening of leaves extract of Neptunia prostrata L. JPAM. 2011;5(2):987-91.

6. Paisooksantivatana Y. Neptunia oleracea Loureiro. In: Siemonsma JS, Piluek K, editors. Plant resources of southeast Asia No. 8. Vegetables. Pudoc, Wageningen, The Netherlands; 1993. p. 217-8.

7. Singha LS, Bawari M, Choudhury MD. An overview on Neptunia oleracea Lour. Assam University J Sci Technol: Biol Environ Sci. 2010;6:155-8.

8. Majumdar K, Datta BK, Das HB, Ray D. Ethnobotanical uses of some plants by tripuri and reang tribes of tripura. Nat Prod Radiance. 2009;8:172-80.
9. Chakraverty R, Aon P, Debnath T, Deb PK, Chakraborty P. Elucidation of the antioxidant and antimicrobial activity of extracts of leaves of Neptunia prostrata Linn. EIJPPR. 2019;9:76-80.

10. Nakamura Y, Murakami A, Koshimizu K, Ohigashi H. Identification of pheophorbide a and its related compounds as possible anti-tumor promoters in the leaves of neptunia oleracea. Biosci Biotechnol Biochem. 1996;60(6):1028-30. doi: 10.1271/bbb.60.1028.

11. Choudhury SN, Paul SB, De B. Preliminary phytochemical evaluation and antibacterial screening of leaves extract of Neptunia prostrata L. JPAM. 2011;5:987-91.

12. Choudhury SN, Paul SB, De B. Structure elucidation of a bioactive compound from the leaves of Neptunia prostrata. Asian J Chem. 2011;24:1469-72.

13. Kirtikar KR, Basu BD. Indian Medicinal Plants, Periodical Experts Books Agency. New Delhi; 1991;2:904.

14. Bhoomannavar VS, Hatapakki BC, Kumar VH, Setty SR, Suresh HM. Laxative activity of pods of Neptunia oleracea in mice. Indian J Nat Prod. 2004;20:43-5.

15. Ghosh R, Jajo H, Acharya PC. An overview of Neptunia prostrata: A source of herbal medicine of ethnopharmacological importance. Glob J Pharmaceu Sci. 2017;2(1). PMID 555577.

16. Ong HC. Vegetables for health and healing. Utusam publication. Kuallampur. 2008;187.

17. Deb PK, Das S, Bhaumik KN, Ghosh R, Ghosh TK, Bhakta T. Pharmacognostic and preliminary phytochemical investigations of Neptunia prostrata L. J Pharmacogn Phytochem. 2013;2:5-11.

18. Das KK, Das SN, DasGupta S. The influence of ascorbic acid on nickel-induced hepatic lipid peroxidation in rats. J Basic Clin Physiol Pharmacol. 2001;12(3):187-95. doi: 10.1515/ jbcpp.2001.12.3.187, PMID 11762690.

19. Abraham P, Wilfred G, Ramakrishna B. Decreased activity of hepatic alkaline protease in rats with carbon tetrachlorideinduced liver cirrhosis. Indian J Exp Biol. 1999;37(12):1243-44. PMID 10865892.

20. Malik JK, Sharma A, Singh S, Jain S. Nanosuspension of vaccine from Adhatoda vasica: isolation and characterization. Drug Invent Today. 2013;5(1):32-8. doi: 10.1016/j.dit.2013.03.005.

21. Bhoomannavar VS, Shivakumar SI, Hallikeri CS, Hatapakki BC. Hepatoprotective activity of leaves of Neptunia oleraceae Lour in carbon tetrachloride-induced rats. RJPBCS. 2011;2:309-11.

22. Stahl E. Thin layer chromatography. 2nd ed. New York: Springer Verlag; 1969.

23. Meena $\mathrm{R}$, Thangam RT, Prabavathy $\mathrm{H}$. Indigenous Medicinal usages of some Macrophytes of the wetlands in Agasteeswaram, Kanyakumari District. Tamil-Nadu J Basic Appl Biol. 2010;4(3):117-22.

24. Yadav RNS, Agarwala Munin. Phytochemical analysis of some medicinal plants. J Phytol. 2011;3(12):10-4.

25. Joseph BS, Kumbhare PH, Kale MC. Preliminary phytochemical screening of selected medicinal plants. IJSR. 2013;1(2):55-62.

26. Tiwari P, Kumar B, Kaur M, Kaur G, Kaur H. Phytochemical screening and extraction: a review. Int Pharm Sci. 2011;1(1).

27. Jain A, Soni M, Deb L, Jain A, Rout SP, Gupta VB, Krishna KL. Antioxidant and hepatoprotective activity of ethanolic and aqueous extracts of Momordica dioica Roxb. Leaves. J Ethno. 2008;115:61-6. doi: 10.1016/j.jep.2007.09.009.

28. Kulkarni SK. Handbook of experimental pharmacology. New Delhi: Vallabh Prakashan; 1993. p. 78-81.

29. Tattini M, Galardi C, Pinelli P, Massai R, Remorini D, Agati G. Differential accumulation of flavonoids and hydroxycinnamates in leaves of Ligustrum vulgare under excess light and drought stress. New Phytol. 2004;163(3):547-61. doi: 10.1111/j.14698137.2004.01126.x, PMID 33873733.

30. Lahon K, Das S. Hepatoprotective activity of Ocimum sanctum alcoholic leaf extract against paracetamol-induced liver damage in Albino rats. Pharmacognosy Res. 2011;3(1):13-8. doi: 10.4103/0974-8490.79110. PMID 21731390.

31. Tran QL, Adnyana IK, Tezuka Y, Nagaoka T, Tran QK, Kadota S. Triterpene saponins from Vietnamese ginseng (Panax vietnamensis) and their hepatocytoprotective activity. J Nat Prod. 2001;64(4):456-61. doi: 10.1021/np000393f, PMID 11325227. 